\title{
UMA ANÁLISE HERMENÊUTICO-GARANTISTA DAS RAZÕES DE DECIDIR DO SUPREMO TRIBUNAL FEDERAL NA APLICAÇÃO DO ART. 28 DA LEI DE DROGAS
}

\author{
A HERMENEUTICAL-GUARANTEEIST ANALYSIS OF THE RATIO DECIDENDI IN \\ BRAZIL'S SUPREME COURT DECISION ABOUT THE APPLICATION OF ART. 28 OF \\ THE DRUG ENFORCEMENT ACT
}

\begin{abstract}
Andréa De Boni Nottingham
Mestra pelo Programa de Pós-Graduação em Direito Constitucional da Universidade de Fortaleza - PPGD/UNIFOR. Pós-graduada em Direito e Processo Tributário pela Universidade de Fortaleza - UNIFOR. Bacharel em Direito pela Universidade de Fortaleza- UNIFOR. Advogada. E-mail: andreadeboni@edu.unifor.br
\end{abstract}

\begin{abstract}
Nestor Eduardo Araruna Santiago
Pós-Doutor pela Escola de Direito da Universidade do Minho, Doutor em Direito Tributário, Mestre e Especialista em Ciências Penais pela Universidade Federal de Minas Gerais (UFMG). Professor Titular do Programa de Pós-Graduação em Direito Constitucional da Universidade de Fortaleza (UNIFOR - Mestrado e Doutorado). Líder do Grupo de Pesquisa "Tutela penal e processual penal dos direitos e garantias fundamentais" (UNIFOR), vinculado ao Laboratório de Ciências Criminais (LACRIM-UNIFOR). Membro do IBRASPP - Instituto Brasileiro de Processo Penal, sendo Coordenador Regional do Estado do Ceará. Advogado Criminalista. E-mail: nestoreasantiago@gmail.com
\end{abstract}

Eduardo Rocha Dias

Doutor em Direito pela Universidade de Lisboa, Mestre em Direito - Ordem Jurídica e Constitucional - pela Universidade Federal do Ceará (UFC). Professor Titular do Programa de Pós-Graduação em em Direito Constitucional da Universidade de Fortaleza (UNIFOR - Mestrado e Doutorado). Procurador Federal. E-mail: eduardodias@hotmail.com

Recebido em: 21/11/2016

Aprovado em: 13/06/2017

Doi: $10.5585 / \mathrm{rdb} . v 18 \mathrm{i} 7.488$

RESUMO: A constitucionalidade do art. 28 da Lei de Drogas está atualmente em discussão no Supremo Tribunal Federal. Essa não é a primeira vez que referido artigo é objeto de análise naquela Corte. Em julgamentos anteriores já se questionou acerca da incidência do princípio da insignificância no crime em questão, bem como já se examinou se a Lei n. 11.343, de 23 de agosto de 2006, teria despenalizado ou descriminalizado a conduta de porte de drogas para consumo próprio. Diante disso, o objetivo da presente pesquisa consiste em realizar uma análise crítica dos fundamentos das decisões do Supremo Tribunal Federal na aplicação do art. 28 da Lei de Drogas, a partir do marco teórico da hermenêutica constitucional contemporânea, bem como analisar qual seria a decisão mais adequada ao Estado de Direito. Utiliza-se de técnica de pesquisa bibliográfica e documental. Quanto aos objetivos, a pesquisa é explicativa, pois o intuito é verificar os argumentos que fundamentam as decisões do Supremo Tribunal Federal sobre a

Revista de Direito Brasileira | São Paulo, SP | v. 18 | n. 7 | p. 191 - 213 |Set./Dez. 2017 
temática e daí retirar uma possível conclusão a respeito de uma decisão futura, ressaltando a importância de esta ser condizente com os ditames do Estado Democrático de Direito Garantista.

Palavras-chave: Supremo Tribunal Federal. Hermenêutica constitucional. Garantismo. Lei de Drogas.

ABSTRACT: The constitutionality of the article 28 of the Drugs Enforcement Act is under discussion in the Supreme Court. This is not the first time the same article is analyzed by the Court. In previous trials, the application of the principle of insignificance upon this crime, as well as the Law n. 11.343, of August 23, 2006, were questioned as ways of decriminalizing drug possession for personal consumption behavior. The objective of this article is to analyze the reasons adopted by the Supreme Court in order to decide how to interpret the article 28 of the Drugs Enforcement Act, considering contemporary constitutional hermeneutics. It will also attempt to determine which would be the most appropriate decision in terms of integrity and consistency, for the preservation of the rule of law. For that end, the paper follows a bibliographic and documentary research are used. As for the objectives is explanatory, because the purpose is to verify the arguments that base the decisions of the Federal Supreme Court on the subject and, based on that, to draw a possible conclusion about a future decision, emphasizing the importance of this being consistent with the dictates of the Democratic State of Law.

Keywords: Supreme Court. Constitutional hermeneutics. Guaranteeism. Drugs Enforcement Act.

SUMÁRIO: Introdução; 1. A hermenêutica constitucional contemporânea e o papel do Supremo Tribunal Federal; 2. Análise das razões de decidir do Supremo Tribunal Federal na aplicação do art. 28 da Lei de Drogas; 3. A possibilidade de declaração de inconstitucionalidade do art. 28 da Lei de Drogas; Conclusão e Referências.

\section{INTRODUÇÃO}

Atualmente, encontra-se em discussão perante o Supremo Tribunal Federal (STF) a constitucionalidade do art. 28 da Lei n. 11.343, de 23 de agosto de 2006 (Lei de Drogas), que prevê como crime a conduta de portar drogas para consumo próprio. O pedido de inconstitucionalidade formulado nos autos do Recurso Extraordinário (RE) n. 635.659, com repercussão geral reconhecida, baseia-se, em resumo, na alegação da Defensoria Pública do Estado de São Paulo de que o mencionado dispositivo viola os direitos fundamentais à privacidade e à intimidade, previstos no art. 5, inciso X, da Constituição Federal de 1988 (CF).

Até o presente momento, apenas três Ministros, Gilmar Mendes, Luiz Edson Fachin e Luís Roberto Barroso, manifestaram-se no caso, todos eles a favor da procedência do pedido de inconstitucionalidade. Essa não é a primeira vez que o art. 28 da Lei de Drogas é objeto de análise pelo STF. Já houve outras discussões envolvendo o dispositivo, tanto no que diz respeito à aplicação dos princípios da insignificância e da ofensividade às condutas vinculadas ao mencionado artigo, quanto acerca do fato de a Lei n. 11.343/2006, ao entrar em vigor, ter descriminalizado ou despenalizado a conduta de porte de drogas para consumo próprio.

A questão que envolve o crime de porte de drogas para consumo próprio é um problema que transcende a esfera jurídica. Trata-se de uma discussão atinente a todas as camadas da sociedade e, como tal, deveria ser debatida democraticamente pelos representantes do povo e não unicamente pelo órgão de cúpula do Poder Judiciário. Porém, diante da inércia dos parlamentares, o tema chegou ao STF, que não pode se eximir de decidir o caso.

Muito embora esse não seja o meio mais legítimo para debater sobre o assunto, a decisão que se encontra nas mãos dos Ministros do STF representará, provavelmente, o primeiro passo para uma mudança em relação à política de drogas até então vigente. E, é nesse contexto, que se 
encontra o problema de pesquisa do presente artigo: É possível, a partir da análise das razões de decidir do julgamento de casos anteriores sobre o art. 28 da Lei de Drogas, bem como da análise dos votos já prolatados nos autos do RE 635.659, saber qual será a decisão final para este caso? Qual seria, dentro do Estado Democrático de Direito garantista, a melhor decisão a ser tomada?

Diante disso, o objetivo geral é analisar criticamente as razões de decidir daquela Corte em relação à aplicação do art. 28 da Lei n. 11.343/2006, adotando-se como marco teórico a metódica estruturante de Friedrich Müller e a Teoria do Garantismo de Luigi Ferrajoli. Os objetivos específicos são: verificar os aspectos contemporâneos que envolvem a hermenêutica constitucional, especificamente no que diz respeito à metódica estruturante, e o papel do STF no Estado Democrático de Direito brasileiro; bem como avaliar se este órgão está seguindo um padrão hermenêutico nas decisões em que trata da aplicação do art. 28, da Lei de Drogas, que permita a aferição de uma previsibilidade da decisão futura sobre a inconstitucionalidade do dispositivo; e, por fim, qual seria a possibilidade de decisão mais adequada ao Estado Democrático de Direito garantista.

Pode-se destacar, desde já, que em julgamentos anteriores o STF consolidou o entendimento, ainda que não unânime, pela inaplicabilidade dos princípios da insignificância ou da ofensividade ao crime de porte para consumo pessoal nos casos envolvendo militar e a instituição castrense; não pelo fato de a conduta violar o bem jurídico saúde pública, mas, principalmente, pela natureza jurídica da relação entre o acusado e a instituição militar à qual se vincula, que tem como princípios peculiares a hierarquia e a disciplina.

Fora do âmbito das relações militares, alguns Ministros também não reconhecem a aplicabilidade dos princípios da insignificância ou da ofensividade para afastar a tipicidade material do crime de porte de drogas para consumo próprio, sob o argumento de que se trata de crime de perigo abstrato, para os quais não se faz necessária a efetivação da lesão ao bem tutelado para efeito de consumação do crime.

No que diz respeito à decisão do STF, no julgamento do RE n. 430.105, que discutiu a natureza jurídica do art. 28 da Lei n. 11.343/2006 logo que esta foi promulgada, os Ministros entenderam pela permanência do caráter criminoso da conduta, de modo que a Lei mencionada teria apenas gerado a despenalização e não a descriminalização, ou seja, limitou-se a substituir a previsão de pena privativa de liberdade por restritiva de direitos, o que é permitido pela $\mathrm{CF}$, no art. $5^{\circ}$, inciso XLVI, que também prevê a possibilidade de atribuição desse tipo de sanção penal a condutas criminosas.

Considerando apenas o teor das decisões anteriores envolvendo a aplicabilidade do art. 28 da Lei de Drogas, bem como suas razões de decidir, seus fundamentos, pode-se partir da hipótese de que dificilmente o RE n. 635.659 teria êxito em relação ao intuito de descriminalizar a conduta de portar drogas para consumo próprio. Caso os Ministros seguissem os mesmos raciocínios já manifestados nos casos anteriores envolvendo a temática, a tendência seria a continuidade da criminalização de tais casos.

Porém, a composição plenária do STF sofreu algumas modificações em relação às decisões anteriores sobre o mesmo tema e o julgamento do processo atual, o que pode representar uma possível mudança de posicionamento do Tribunal. Os novos Ministros podem adotar novas formas de interpretar e, consequentemente, de decidir, mais familiarizadas com a hermenêutica constitucional contemporânea que aproxima a norma da realidade, o que pode trazer um resultado diferente para o julgamento do RE n. 635.659.

De qualquer forma, é importante ressaltar que, independentemente da mudança de composição, o STF, enquanto órgão do Estado Democrático de Direito brasileiro, tem o dever de manter suas decisões estáveis, íntegras e coerentes, conforme aduz o art. 926 do Código de Processo Civil. Esta exigência busca garantir, sobretudo, a segurança jurídica, daí a relevância de que os Ministros adotem um método de hermenêutica constitucional para fundamentar seus entendimentos. 
Partindo do posicionamento hermenêutico de Friedrich Müller e de sua metódica estruturante, bem como, considerando os ditames presentes na Teoria do Garantismo para legitimação do Estado Democrático de Direito, de Luigi Ferrajoli, pode-se supor, como hipótese inicial, que a decisão mais acertada, ainda que diversa dos casos anteriores, é pela declaração de inconstitucionalidade do dispositivo, o que será verificado no decorrer do presente artigo.

Com o fito de chegar a uma resposta ao problema de pesquisa apresentado, primeiramente faz-se um levantamento bibliográfico e um breve estudo teórico sobre a evolução dos modelos de Estado existentes desde o período iluminista e a sua consequente influência na forma de entender a hermenêutica constitucional, até se chegar na contemporeneidade, destacando-se as contribuições de Ferrajoli, no que diz respeito à Teoria legitimadora de um Estado de Direito, e de Muller, no que diz respeito à hermenêutica constitucional contemporânea.

Feito isso, em um segundo momento, realiza-se uma análise crítica dos fundamentos apresentados em decisões anteriores do STF acerca da aplicação do art. 28 da Lei de Drogas em casos concretos, mais uma vez levando em conta os pressupostos trazidos na análise teórica das Teorias de Muller e Ferrajoli, adotando-se como técnica metodológica a pesquisa bibliográfica e documental do tipo pura, baseada, primordialmente, em estudos de artigos de periódicos e livros de doutrina, bem como na análise de dispositivo legal e das razões de decidir dos julgamentos selecionados no sistema de busca de jurisprudência do sítio eletrônico do STF, tudo com a fito de ampliar o conhecimento e fomentar a discussão sobre o assunto.

Por fim, na terceira etapa do desenvolvimento do presente artigo, apresenta-se uma análise crítica e hipotética das razões de decidir dos três votos já prolatados no curso do julgamento do RE 635.659. A ideia é apresentar esses votos e compará-los com o teor das decisões anteriores, a fim de que assim possa-se estimar como se dará o andamento da discussão no Plenário do STF, diante daqueles Ministros que ainda não expressaram seus argumentos. Como só há, até o presente momento, três votos de onze necessário para o encerramento do caso, só se pode prever a decisão final a título de hipótese, com base naquilo que já se tem de contreto.

Tendo em vista esse caminho metodológico percorrido, que se aproxima da análise do discurso crítico de Foucault, a abordagem da pesquisa pode ser definida como qualitativa em todos os seus aspectos, vez que parte de uma reflexão e de um estudo teórico-descritivo e explicativo sobre ações humanas e sociais, portanto, analisa experiências subjetivas e não quantitativas. Quanto aos objetivos, é explicativa, ao passo que busca interpretar os objetos investigados, a fim de esclarecer o fenômeno observado. Em outras palavras, parte-se da análise dos argumentos utilizados nas decisões em que o STF avaliou a aplicabilidade do art. 28 da Lei de Drogas, a fim de verificar se os Ministros seguiram um raciocínio hermenêutico padronizado de onde se possa inferir qual seria a decisão final no julgamento do RE 635.659.

Dessa forma, em síntese, levando em consideração aspectos que envolvem a hermenêutica constitucional contemporânea, ou seja, aquela que se firmou após o período da Segunda Guerra Mundial, sobretudo, com base nas teorias de Friedrich Müller e de Luigi Ferrajoli, após fazer uma avaliação hermenêutica das razões de decidir do STF em casos anteriores envolvendo o art. 28 da Lei de Drogas, passou-se à análise dos três votos já prolatados no RE n. 635.659, tendo em vista que o julgamento ainda não foi concluído, tudo a fim de perquirir qual seria a decisão hermeneuticamente compatível com o Estado Constitucional Democrático de Direito garantista, sem deixar de considerar o princípio da segurança jurídica, que exige decisões coerentes e íntegras.

Destarte, o desenvolvimento do presente artigo está dividido em três tópicos: no primeiro será abordada a hermenêutica constitucional contemporânea, entendida esta como o novo panorama surgido após a Segunda Guerra Mundial, quando as Constituições passaram a ter força normativa, considerando, primordialmente, as teorias de Friedrich Müller e de Luigi Ferrajoli, bem como, será abordado, em linhas gerais, o papel do STF a partir dessa nova hermenêutica constitucional. 
No segundo tópico analisam-se algumas decisões do STF acerca da aplicabilidade do art. 28 da Lei de Drogas, a fim de verificar, hermeneuticamente, as razões de decidir desse Tribunal. Para encerrar, no terceiro e último tópico, discute-se a respeito dos votos já prolatados no julgamento acerca da inconstitucionalidade do art. 28 da Lei n. 11.343/2006, sob o viés da hermenêutica constitucional apresentada no primeiro tópico, assim como sobre a necessidade de se tomar uma decisão coerente e íntegra, que garanta a segurança jurídica imprescindível ao Estado de Direito garantista.

\section{A HERMENÊUTICA CONSTITUCIONAL CONTEMPORÂNEA E O PAPEL DO SUPREMO TRIBUNAL FEDERAL}

A partir da Revolução Francesa, em confronto com os governos monárquicos absolutistas, em que a vontade do Rei era lei e o Poder Judiciário não tinha independência, surgiu o movimento positivista-legalista, que determinava a previsão expressa e declarada dos direitos por meio de lei prévia e imposta, a fim de poder ser objeto de cognição de todos. A tarefa do intérprete era objetiva, alheia a qualquer interferência externa diversa do próprio texto legal para garantir o máximo de segurança jurídica possível (FONTOURA et al, 2011, p. 316; TAVARES, 2009, p.15).

Neste período, entre o final do século XVIII e a metade do século XX, as Constituições eram apenas cartas políticas, sem aplicabilidade imediata, consideradas meramente indicativas da atuação do legislador, a quem cabia obedecer somente ao processo formal de elaboração da lei para que esta fosse válida. A lei era a única fonte do Direito e, por isso, imperava, de modo que os direitos fundamentais tinham aplicabilidade apenas à medida que fossem previstos e regulamentados por ela (SARMENTO, 2009, p. 34-35).

O Estado, nessa época, consubstanciou-se como Estado legalista, em que todas as atividades ficavam adstritas aos parâmetros legais, e ao Poder Judiciário cabia efetivar a lógica subsuntiva dos fatos à letra fria da lei, sem considerar de qualquer forma ou a ordem política, ou a justiça, ou mesmo a adequação à realidade social: o Direito era desvinculado da realidade (SARMENTO, 2009, p. 35; TAVARES, 2009, p. 21).

Nesse viés positivista, o Direito é um sistema jurídico sem lacunas, que se auto-integra a partir de enunciados presentes no próprio ordenamento jurídico ou nos princípios gerais de direito positivo. Lei e texto da lei são a mesma coisa, o texto deve ser interpretado por meio de regras objetivas e essa interpretação equivale à sua concretização. A atividade interpretativa não passa de uma reelaboração da vontade do legislador que se manifesta no texto da norma, na sua história legislativa, no nexo sistemático com outros textos e normas, ou nas finalidades das prescrições (MULLER, 2005, p. 7 e 24-25).

O positivismo legalista trouxe uma grande contribuição para o Direito: a segurança jurídica e o limite ao poder estatal, pois retirou do mundo jurídico a possibilidade de casos concretos serem regulados por normas posteriores, elaboradas de forma direcionada e parcial, como também buscou eliminar influências subjetivas dos aplicadores das leis, que ficaram restritos aos comandos expressos. Este positivismo consubstanciou um Estado legalista, em que todos os poderes estavam vinculados à lei formal, a ela submetidos e por ela limitados.

Por outro lado, engessou o Direito, dissociou-o da realidade da qual ele emerge, além do que, como a lei era a única fonte que imperava, o legislador era o único autor do Direito, ao Poder Judiciário caberia apenas a aplicação da letra fria da lei, de forma exegética, sem poder interpretá-la progressivamente para adaptá-la à realidade do momento e do caso concreto específico. Perdeu-se de vista a consciência de que o Direito é uma ciência social aplicada, que nasce dos fatos e por eles é influenciado.

Esse positivismo formalista foi questionado, ainda no século XIX e no início do século XX, por movimentos como a Escola do Direito Livre, a jurisprudência dos interesses e a 
jurisprudência dos conceitos. Posteriormente, chega-se à fase normativista do positivismo (STRECK, 2012a, p. 33), em especial com Kelsen, distinguindo-se um ideal de pureza, alheio a valorações, traduzido nos enunciados da Ciência do Direito e da Política, que, em última análise, contribuiriam para o preenchimento da moldura da norma (KELSEN, 1984, p. 337).

Após o fim da Segunda Guerra Mundial, quando as Constituições passaram a prever uma série de direitos fundamentais de aplicabilidade imediata, que dispensam a intermediação da lei, e de conteúdo semântico aberto, que exigem uma atividade interpretativa que vá além da literalidade do texto, houve uma modificação da atuação do Poder Judiciário, que se torna responsável pela aplicação direta desses direitos e, por conseguinte, pelo preenchimento de seus conceitos indeterminados (SARMENTO, 2009, p. 35-36).

As atrocidades cometidas durante o período de guerra, justificadas e amparadas nos ditames legais que fundamentavam e legitimavam a existência de Estados Nazifascistas, em que não havia qualquer preocupação com as condições e com os direitos humanos, serviram de alerta para a necessidade de mudança em relação ao sistemas jurídicos existentes. O Direito e a sua forma de aplicabilidade passou a ser questionado (SCHEIFER; MANDALOZZO; CAMPAGNOLI, 2016, p. 162).

A partir da segunda metade do século XX, ocorrem algumas transformações na metodologia jurídica. A Constituição passa a ser o centro do ordenamento e, com isso, surge o movimento constitucionalista, que se divide em duas diferentes concepções (FERRAJOLI, 2012, p. 8): de um lado, os que aqui serão chamados de neoconstitucionalistas, que buscam negar o positivismo, superá-lo; do outro, aqueles que reafirmam o positivismo, porém, não mais de modo puramente formalista e legalista, buscam acrescentar um viés substancial, sem perder de vista a necessidade de respeito aos ditames formais do Direito, que aqui serão representados por Ferrajoli e Müller.

Para os neoconstitucionalistas, há uma reaproximação necessária entre Direito e Moral; os direitos fundamentais têm natureza de princípios que, por sua vez, instrumentalizam valores éticos, cujo conflito resolve-se por meio de ponderação ou balanceamento, em que o poder da argumentação define a solução para o caso, de modo que a atividade judicial se destaca das demais; o juiz torna-se protagonista do Direito ao exercer uma função criativa por meio da atividade interpretativa e argumentativa (NEVES; TEIXEIRA, 2014, p. 177; SARMENTO, 2009, p. 40).

A tendência neoconstitucionalista abre margem para interpretações subjetivas do texto constitucional e, consequentemente, contraria completamente a conquista que o positivismo teve com a garantia de segurança jurídica, pois o aplicador do Direito fica inteiramente livre das amarras da lei para, por intermédio de seus argumentos, inclusive os de cunho eminentemente moral, tomar a decisão que entender ser a mais acertada e justa ao caso concreto, o que pode gerar um resultado solipsista, que leva em consideração apenas a própria experiência de vida do julgador.

Em sentido contrário, destaca-se, no que diz respeito primeiramente a uma teoria constitucional, o garantismo, defendido por Luigi Ferrajoli, para quem o constitucionalismo contemporâneo deve se traduzir em uma reafirmação do positivismo, com inserção de conteúdo à norma. O constitucionalismo garantista não aceita a reaproximação entre Direito e Moral, pois assinala que essa distância é extremamente importante à limitação da atividade judicial, para impedir que arbitrariedades sejam justificadas moralmente (NEVES; TEIXEIRA, 2014, p. 177).

A teoria garantista, como Teoria do Direito, ressalta a diferença entre vigência e validade, pois, enquanto vigência refere-se à conformidade formal da lei à Constituição, a validade refere-se à conformidade material, impondo um novo limite ao legislador. A democracia ganha uma dimensão substancial, pois se realiza pelo Direito e por intermédio dele, ou seja, com base nos direitos fundamentais positivados; ao juiz cabe remover antinomias e apontar lacunas, 
sem que possa, por meio de uma atividade criativa, preenchê-las com princípios morais (FERRAJOLI, 2012, p. 22 e 39; STRECK, 2012b, p. 69).

Dessa forma, por intermédio do garantismo, a atividade limitadora do Direito posto continua a se impor para manter a segurança jurídica das relações sociais e dos indivíduos em relação ao Estado, porém, de uma forma que vai além da instituída pelo positivismo tradicional, pois agora não há uma limitação meramente formal, mas também uma limitação substancial, que atinge tanto o legislador, ao normatizar condutas, quanto ao juiz e ao administrador, que ficam restritos ao comando legal, formal e substancialmente constitucional.

Esse movimento constitucionalista contemporâneo, caracterizado aqui como aquele que surge após a Segunda Guerra Mundial, como já mencionado, deu ensejo a transformação da hermenêutica constitucional, vez que a atividade de interpretação da lei em relação à Constituição não pode mais ficar vinculada unicamente a aspectos formais, sendo necessário um redirecionamento de métodos hermenêuticos que permitam a avaliação do conteúdo da norma, sem, contudo, dissociar-se das regras que regem o Estado de Direito.

Essa defesa de aproximação do Direito à realidade e o consequente distanciamento para a moralidade subjetivista, que marca tanto a teoria de Friedrich Muller, quanto a Teoria de Ferrajoli, sofreu influência das discussões empreendidas por Hans-Georg Gadamer, cujo projeto marcou o nascimento da hermenêutica contemporânea. Gadamer, em defesa da linguisticidade do ser, aponta para a circunstância de a realidade ser conhecida por meio da linguagem. A revelação do ser se mostra como fenômeno ao mesmo tempo ontológico e epistemológico. Não há, portanto, uma separação entre sujeito que conhece e a realidade: ambos se encontram imersos na linguagem e na história.

Gadamer (2010, p. 108) destaca o momento da aplicação, presente na hermenêutica jurídica e também teológica, como característico da superação entre a generalidade da norma e a especificidade do caso. A princípio, Gadamer não se importa com o tema do método, já que sua preocupação é determinar como a tradição e o passado afetam a compreensão, evidenciando o caráter ontológico desta última (PALMER, 1999, p. 198). Não se interessa ele em apontar como se pode chegar a decisões objetivamente válidas. As pré-compreensões do intérprete, a fusão de seu horizonte com o horizonte do texto e a necessidade de uma consciência efetivamente mostram-se como condições de possibilidade da compreensão.

O papel do intérprete na construção do sentido é destacada. Mas, foi por meio das teorias contemporâneas da argumentação que se realçou o caráter argumentativo da prática do Direito, sobretudo o desempenhado por órgãos de aplicação (Judiciário, Administração e outros) e também pela Teoria (ou dogmática) do Direito, ao fornecer critérios para produção, aplicação e sistematização do Ordenamento Jurídico (ATIENZA, 2000, p. 19).

A teoria da argumentação jurídica, nessa toada, é "a versão contemporânea da velha questão do método jurídico" (ATIENZA, 2000, p. 170). Dentre as teorias atuais da argumentação, destacam-se as propostas por Alexy, Teoria da Argumentação Jurídica (Theorie der juristichen Argumentation), e por Neil MacCormick, na obra Argumentação Jurídica e Teoria do Direito (Legal Reasoning and Legal Theory), que, apesar de desenvolvidas em diferentes tradições jurídicas, chegam a conclusões bastante semelhantes.

Muito embora não caiba aqui o desenvolvimento do tema, é importante lembrar o projeto de MacCormick, de construir uma proposta que se situe a meio caminho entre uma teoria ultrarracionalista do Direito - como a de Dworkin e sua tese da única resposta correta - e uma irracionalista - como a de Ross, de que as decisões são arbitrárias, fruto da vontade e não da razão. A argumentação prática em geral e a argumentação jurídica, em particular, cumprem uma função de justificação. Mesmo quando pretendem persuadir, os argumentos têm de ser justificados, de acordo com os fatos estabelecidos e as normas vigentes.

Parte MacCormick da distinção entre contexto da descoberta e contexto da justificação, situando sua teoria na segunda, de forma a buscar identificar as razões que mostrem que as 
decisões garantem “a justiça de acordo com o Direito" (ATIENZA, 2000, p. 172). Justificar uma decisão, sobretudo em casos difíceis, significa cumprir o requisito da universalidade e também que a decisão tenha sentido em relação ao sistema (cumpra requisitos de consistência e de coerência) e em relação ao mundo, implicando considerações com suas consequências (ATIENZA, 2000, p. 182-183). O exame da coerência das decisões do STF no tocante ao art. 28 da Lei de Drogas deve ser efetuado, portanto, levando em conta tais requisitos.

Nesse diapasão, inspirados nesses fontes, destaca-se a Teoria da Metódica Estruturante de Friedrich Müller, que, assim como Ferrajoli, não reconhece a superação total do positivismo, mas, especificamente no que diz respeito à hermenêutica constitucional contemporânea, denuncia a insuficiência dos métodos até então utilizados para concretização de direitos fundamentais e constitucionais, motivo pelo qual propõe uma reaproximação do Direito, não com a Moral, mas com a realidade, já que a norma, instrumento de expressão do Direito, é produto da realidade e, portanto, dela é indissociável (BONAVIDES, 2005; MÜLLER, 2005, p. 22).

Müller, a partir do questionamento do que é norma jurídica, extrai a ideia fundamental de sua teoria: texto da norma não é o mesmo que norma, pois esta é o resultado da interação entre o Direito e a realidade, ou seja, enquanto o texto possui apenas o elemento da positividade, a norma é o resultado da soma desse elemento com o elemento realidade, por meio da metódica estruturante, que confere à norma a normatividade, tornando-a capaz de produzir efeitos (FONTOURA et al, 2011, p. 327).

O texto da norma é apenas o ponto de partida para a sua concretização, pois não é o texto que regulamenta o caso, mas o legislador, o jurista, o administrador, ao elaborar, publicar e fundamentar a decisão do caso concreto, realizando a complementação a partir dos fatos, sem perder de vista os limites impostos pela literalidade dessa norma constitucional, bem como outros meios metódicos que auxiliam a concretização (MÜLLER, 2005, p. 38-39).

A norma é o resultado de dois elementos que surgem de seu processo de concretização: o programa da norma e o âmbito da norma. O programa da norma é o teor literal, que lhe confere positividade, enquanto o âmbito da norma é o recorte da realidade social correspondente ao programa da norma. Ambos são elementos de mesma e hierarquia e não podem ser aferidos de forma autônoma, isso porque, os aspectos de realidade fazem parte da própria formação do programa da norma, enquanto os aspectos jurídicos também limitam o âmbito da norma. Há uma interconexão entre esses elementos (FONTOURA et al, 2011, p. 332-334; MÜLLER, 2005, p. 42-43).

Tendo em vista essas premissas, Müller propõe uma metódica estruturante para guiar a hermenêutica constitucional. Metódica, pois o método é essencial para conferir cientificidade ao Direito e segurança às decisões; estruturante, porque parte justamente da análise da estrutura da norma, dos elementos que a compõem, que não se confunde unicamente com a os aspectos linguísticos, mas também não dispensa sua importância dentro do Estado de Direito. Daí pode dizer-se que, assim como Ferrajoli, Müller anuncia uma reformulação do positivismo, e não sua superação (LAKATOS; MARCONI, 2003, p. 83; MÜLLER, 2005, p. 2-3).

O processo de concretização da norma divide-se em dois grupos: o primeiro refere-se ao texto da norma e seus métodos tradicionais de interpretação, como também a dogmática, a teoria, a ordem jurídica, dentre outros; o segundo, ao âmbito da norma. Daí por que Müller prefere falar em concretização à interpretação, pois a atividade do aplicador do Direito não fica adstrita a literalidade do texto para enfim aplicá-la, mas se vincula obrigatoriamente a elementos da realidade e do caso concreto, o que traduz uma atividade prática do juiz (FONTOURA et al, 2011, p. 336).

A porta de entrada da metódica estruturante é a assimilação das pré-compreensões do jurista em combinação com os elementos linguísticos do texto e com a realidade que circunda o caso. Esta é a fase de abertura ao processo de concretização. Posteriormente, numa segunda fase, já propriamente da metódica, o aplicador deverá selecionar as prescrições jurídicas relevantes ao 
caso e os fatos da realidade que realmente importam ao Direito. A partir de então o aplicador fará uma análise gramatical, sistemática, histórica, teleológica, dogmática, teórica e política, que o conduzirá ao programa da norma (FONTOURA et al, 2011, p. 338).

$\mathrm{Na}$ fase seguinte, partindo do programa da norma já formado, o aplicador selecionará os fatos do âmbito do caso, escolhidos ou criados pelo próprio programa para por ele serem regulamentados, que comporão o âmbito da norma. Esse liame entre o programa e os fatos que formam o âmbito da norma exige uma densa fundamentação, para evitar qualquer dúvida no resultado final do julgamento (FONTOURA et al, 2011, p. 338).

Nas duas últimas fases da concretização, cabe ao aplicador, primeiramente, definir a norma geral e abstrata a partir de uma síntese da combinação entre o programa da norma e o âmbito da norma e, posteriormente, decidir o caso, por meio da formação da norma individual e concreta, a chamada norma da decisão, confrontando os elementos provenientes do sistema jurídico e os da realidade (FONTOURA et al, 2011, p. 339).

A importância do desenvolvimento de uma metódica estruturante está em fornecer meios para que a decisão possa ser objeto de controle, mediante a revisão de uma fundamentação que represente os elementos de concretização da norma. A metódica confere legitimidade democrática à decisão, pois permite o reconhecimento dos aspectos analisados, sem tirar da ciência jurídica a possibilidade de discussão dos resultados e de seus modos de fundamentação, inerentes ao Estado Democrático de Direito (FONTOURA et al, 2011, p. 335; MÜLLER, 2005, p. 53-57).

Müller destaca que em caso de conflitos entre os elementos que compõe o programa da norma e os elementos que compõem o âmbito da norma, os textuais devem sempre prevalecer, como limite essencial imposto pelo Estado de Direito: o aplicador da norma não pode passar por cima do texto constitucional, que sempre se apresentará como restrição à atividade jurisdicional. A teoria de Müller tira a Constituição do marasmo da simbologia, pois confere às normas um valor pragmático, mas não desconhece a importância da conquista de segurança jurídica pelo positivismo.

No Brasil, o movimento do constitucionalismo contemporâneo teve início com a CF, que trouxe em seu bojo uma série de direitos fundamentais e de garantias para assegurá-los, dentre os quais a inafastabilidade da tutela jurisdicional, prevista no art. $5^{\circ}$, inciso XXXV; além de ter democratizado o processo de controle abstrato de constitucionalidade, ampliando o rol dos legitimados para ingressar com a ação, o que intensificou a atuação do STF, a quem se atribui o papel de zelar pelas normas constitucionais (SARMENTO, 2009, p. 43).

Portanto, ao STF, mais do que a qualquer outro órgão do Poder Judiciário brasileiro, direciona-se à necessidade de adoção de uma metodologia hermenêutica, pois, apesar da possibilidade de os demais juízes e Tribunais realizarem controle difuso de constitucionalidade, ao STF cabe a última palavra, que vinculará todos os órgãos do Judiciário e da administração, bem como servirá de parâmetro para as condutas sociais, que se nortearão a partir das decisões desse Tribunal.

No Brasil, o STF assume papel contramajoritário, por meio do qual sua decisão deve prevalecer em relação aos atos do Legislativo e do Executivo, ou seja, tem o poder de invalidar os atos desses dois outros Poderes, compostos por membros eleitos pela maioria do povo (BARROSO, 2015a). Ressalta-se que é da essência do STF essa atuação contramajoritária, pois é inerente à própria jurisdição constitucional, em que um dos aspectos é justamente assegurar a existência das minorias e de seus direitos fundamentais.

Esta, sim, é uma inovação no constitucionalismo contemporâneo: a limitação imposta pela previsão constitucional de direitos fundamentais ao poder das maiorias parlamentares (ABBOUD, 2012, p. 193-194). A legitimidade dessa atuação contramajoritária está na fundamentação da decisão, que deve apresentar padrões hermenêuticos permissivos de controle e discutibilidade, como assevera Müller. 
Portanto, especificamente no que diz respeito à atual discussão acerca da constitucionalidade do art. 28 da Lei de Drogas, faz-se importante analisar as decisões anteriores sobre a aplicação do dispositivo, a fim de aferir se o STF tem cumprido seu papel de efetivar os dispositivos constitucionais, sem perder de vista os aspectos da realidade e, se é possível obter uma previsibilidade sobre a decisão final referente ao julgamento do RE 635.659 pelo STF que traga segurança jurídica e que traduza uma decisão íntegra e coerente dentro do Estado Constitucional Democrático de Direito garantista.

\section{ANÁLISE DAS RAZÕES DE DECIDIR DO SUPREMO TRIBUNAL FEDERAL NA APLICAÇÃO DO ART. 28 DA LEI DE DROGAS}

As decisões envolvendo a aplicação do art. 28 da Lei de Drogas normalmente levam em consideração princípios interpretativos do Direito Penal que não estão expressos na $\mathrm{CF}$, mas implícitos numa ordem de Direito que assimile e considere a teoria do garantismo, cujo principal escopo, na ótica penal, é a adoção de um Direito Penal mínimo, em que este ramo do Direito atue como forma de controle social somente quando nenhum outro ramo for capaz de tutelar os bens jurídicos mais relevantes para o convívio harmônico e pacífico da sociedade (BITENCOURT, 2014, p. 54).

O Direito Penal mínimo objetiva impor limite ao poder punitivo estatal, a fim de que seja aplicado ao criminoso o mínimo mal necessário, por meio de uma sanção penal efetiva e eficaz, e, ao mesmo tempo, visa garantir o máximo de bem-estar possível à sociedade em geral, por meio da promoção de um equilíbrio entre o dever de punir do Estado e o respeito à dignidade da pessoa humana de todos os indivíduos, sejam eles transgressores ou não (FERRAJOLI, 2014, p. 312-313).

Especificamente nos casos que aqui serão analisados, os princípios oriundos dessa premissa são os da insignificância e da ofensividade ou lesividade O primeiro consubstancia-se na faceta do Direito Penal mínimo dirigido à atividade do concretizador do Direito, que deve avaliar, no caso concreto, se a conduta, mesmo que prevista em lei como crime, merece real atenção do Direito Penal, pois existem fatos que, apesar de serem subsumíveis, não chegam a causar lesão ao bem jurídico tutelado, o que torna injustificada a aplicação da sanção penal (LUZ, 2012, p. 207).

Percebe-se que, além de ser uma vertente da teoria do garantismo, o princípio da insignificância também traz à tona a metódica estruturante de Müller, pois exige que o aplicador do Direito, ao verificar a possibilidade de incidência ou não desse princípio, volte-se para a realidade social que circunda o caso concreto, pois a insignificância tem o condão de excluir a tipicidade material do delito, que se refere à valoração da conduta e do resultado do crime, o que deve ser feito por meio de uma análise substancial do caso.

O princípio da ofensividade, por sua vez, refere-se ao objeto de tutela do crime, ou ao resultado da conduta punível, ou seja, conforme esse princípio fica afastada a criminalização de condutas que não lesem bens jurídicos de terceiros, que não excedam o âmbito do próprio autor, que não transcendam a esfera da consciência do indivíduo, que consubstanciem um simples estado ou condição existencial (BATISTA, 2015, p. 90-92).

A necessidade de ofensividade ou lesividade a bem jurídico de terceiro para que determinada conduta possa ser criminalizada é decorrência direta da separação entre Direito e Moral, ideia defendida por Ferrajoli na teoria garantista, como legado, inclusive, do movimento positivista, que não admite a tipificação penal de condutas que sejam apenas moralmente reprováveis, ou seja, que não atinjam terceiros: tais condutas devem ser toleradas tanto pela sociedade quanto pelo Estado. Do contrário, o Direito Penal se dirigiria ao autor e não ao fato, transformando-se em um instrumento para a exclusão das minorias (IPPOLITO, 2011, p. 38). 
Essa necessidade decorre também da própria finalidade do Direito Penal, que, além de ter o caráter repressivo, também tem caráter preventivo. Ademais, não se pode perder de vista que criminalizar condutas indiferentes e inofensivas, ou que visem antecipar o cometimento de determinado crime que sequer tenha ultrapassado a esfera da possibilidade, ao invés de prevenir delitos, faz com que surjam delitos novos (BECCARIA, 2011, p. 115).

Vale ressaltar que o STF, em casos que envolvem o art. 28 da Lei de Drogas, já mencionou em suas razões de decidir a inaplicabilidade de ambos os princípios, da insignificância e da ofensividade. Aliás, normalmente, no que diz respeito a este último, os Ministros não costumam realizar uma argumentação mais profunda para justificar o seu afastamento, mas se limitam a verificá-lo como um dos vetores de incidência da insignificância, para a qual criou como parâmetro de aferição quatro critérios objetivos e dentre eles fez constar a mínima ofensividade da conduta (BRASIL, 2004, p. 229).

A análise de tais princípios pelo STF nos casos até então julgados, que envolviam o crime de porte de drogas para consumo próprio, não foi suficiente para afastar o caráter criminoso da conduta, pois, até a atual discussão acerca da inconstitucionalidade do art. 28 da Lei n. 11.343/2006 por meio do RE n. 635.659, o STF vinha preferindo a aplicação do dispositivo e a condenação do usuário ao afastamento do delito, mesmo que de forma não unânime, como se passa analisar.

O primeiro caso que se destaca é de 2007, ano posterior à promulgação da Lei n. 11.343/2006, que revogou a antiga Lei de Tóxicos (Lei n. 6.368/1976) e trouxe como inovação para o crime de porte de drogas para consumo próprio a previsão de pena restritiva de direitos ao invés de pena privativa de liberdade, o que gerou a dúvida acerca da natureza jurídica do delito. Doutrinadores, como por exemplo Luiz Flávio Gomes (2006), passaram a defender que teria havido uma descriminalização da conduta mencionada, uma abolitio criminis, enquanto outros, como Guilherme de Souza Nucci (2012, p. 228), acreditavam que se tratava apenas de uma despenalização.

A descriminalização é o processo pelo qual determinada conduta criminosa deixa de assim ser considerada crime, seja porque teve sua natureza ilícita totalmente abolida, passando a ser conduta permitida para o Direito, seja porque a infração penal é transferida para âmbito de regulamentação de outro ramo sancionatório do Direito, como o administrativo, permanecendo, nesse caso, como ilícito jurídico, mas não mais criminal (CARVALHO, 2014, p. 144).

A despenalização, ou descarcerização, por sua vez, como se pode inferir da própria nomenclatura, significa a suavização da penalização imposta, na tentativa de retirar ou abrandar a pena de prisão para determinada conduta, sem descaracterizar a natureza criminosa da ação. A despenalização equivale à alteração do preceito secundário do tipo penal, correspondente à sanção, que deixa de ser privativa de liberdade para se tornar restritiva de direitos (GOMES, 2006).

Tendo em vista tais conceitos, os Ministros da Primeira Turma do STF, no julgamento da questão de ordem suscitada no RE n. 430.105, sob relatoria do Ministro Sepúlveda Pertence, decidiram pela manutenção da natureza criminosa da conduta de porte de drogas para consumo próprio, prevista no art. 28, da Lei n. 11.343/2006, que teria apenas, nos argumentos prevalecentes do acórdão, despenalizado o crime por meio do abrandamento da pena prevista.

Em seu voto, o relator fez uma análise objetiva do art. 28 , pois suas razões de decidir se justificaram, dentre outras, em uma hipótese que se traduz no critério literal e em duas outras hipóteses que se traduzem no critério sistemático de interpretação. No primeiro caso, alegou o relator, que o legislador inseriu a conduta em discussão no capítulo da Lei cujo título é "Dos crimes e das penas", fato que não poderia ser ignorado, o que acaba sendo produto de uma interpretação que busca satisfazer a vontade do legislador ao editar o texto normativo (BRASIL, 2007, p. 739). 
Nos dois outros argumentos, o Ministro fez uma análise combinada e sistemática de dispositivos do ordenamento jurídico, alegando, primeiramente, que a pena restritiva de direitos estabelecida pelo referido artigo é condizente com o que prevê o art. $5^{\circ}$, inciso XLVI, da CF, também para condutas criminosas, que não ficam adstritas a sanção por meio de prisão; e, posteriormente, que o termo "reincidência", previsto no $\S 4^{\circ}$, do art. 28 , não pode ser interpretado sem levar em consideração o art. 63 do Código Penal (CP), que se refere expressamente a crime (BRASIL, 2007, p. 737 e 739).

Os Ministros Carlos Ayres Britto e Marco Aurélio seguiram o voto do relator, sem acrescentarem nada de novo, enquanto o Ministro Lewandowski foi além e, referindo-se ao princípio da ofensividade, ainda que não de forma direta, enfatizou seu entendimento de que a conduta é lesiva e atinge a sociedade, pois não diz respeito somente à pessoa portadora da droga, o que, na sua visão, era o suficiente para ensejar a manutenção do caráter criminoso da ação (BRASIL, 2007, p. 744).

A decisão final do RE n. 430.105 foi resultado de uma interpretação que fugiu dos padrões exigidos tanto pela teoria garantista, quanto pela metódica estruturante, pois, no primeiro caso, feriu a análise do princípio da ofensividade, que apenas foi citado, mas não fundamentado, por um dos quatro Ministros, que não deixou claro onde estaria presente a lesividade de uma conduta que tem por finalidade essencial o consumo próprio; e, no segundo caso, ficou adstrita aos parâmetros literais do programa da norma, sem avançar para a análise acurada da realidade social, não se discutiu em momento algum qualquer fator pragmático.

Encerrada essa discussão e mantida a natureza criminosa da conduta, em 2010, o Pleno do STF, no julgamento do Habeas Corpus (HC) n. 103.684 (cuja decisão foi publicada apenas no Diário Oficial em abril de 2011), que teve como relator o Ministro Carlos Ayres Britto, avaliou a possibilidade de incidência do princípio da insignificância ao crime de porte de drogas para consumo pessoal em caso que envolvia um recruta do Exército brasileiro preso em flagrante no momento em que consumia ínfima quantidade de maconha dentro da instituição castrense.

Vale ressaltar que, até o julgamento do $\mathrm{HC}$ acima mencionado, as duas Turmas do Tribunal divergiam acerca da aplicação do princípio da especialidade nos casos em que a relação jurídica fosse de natureza militar. Isto porque, o art. 290 do Código Penal Militar (CPM), que é anterior a Lei n. 11.343/2006, tipifica como crime próprio (que pode ser cometido apenas por militar) a conduta de portar drogas para consumo pessoal, e atribui pena mais rígida do que a legislação comum.

Enquanto a Primeira Turma do STF estava aplicando o art. 290 do CPM, tendo em vista a especialidade da relação jurídica, a Segunda Turma estava aplicando o art. 28 da Lei $\mathrm{n}$. 11.343/2006, sob o argumento de que esta é mais benéfica ao réu, por prever sanção mais branda. Dessa forma, a decisão final do HC n. 103.684 uniformizou a jurisprudência, que a partir de então, em casos análogos, passou a decidir com base nesta decisão.

O Ministro relator do HC 103.684, Carlos Ayres Britto, destacou que o problema que envolvia o caso em questão não dizia respeito à quantidade ou à qualidade da droga apreendida com o paciente, mas à natureza da relação jurídica existente entre o recruta e o Exército. Ressaltou que não caberia distinguir, hermeneuticamente, a adequação formal e material do tipo penal, pois no caso específico da relação castrense simplesmente não há que se falar em insignificância (BRASIL, 2010, p. 112).

Explicou que não se aplica o princípio da insignificância porque não se trata unicamente da tutela da saúde pública como bem jurídico-penal, mas do efeito que a conduta causa na moral da corporação e do próprio conceito social das Forças Armadas, cuja finalidade é proteger a ordem democrática, o que não é possível se seus próprios membros não seguem rigorosamente as ordens hierárquica e disciplinar interna, valores com previsão no art. 142, CF (BRASIL, 2010, p. $115)$. 
O Ministro Carlos Ayres Britto encerrou seu voto denegando a ordem e manifestando-se pela incidência do art. 290 do CPM, não do art. 28 da Lei n. 11.343/2006, por se tratar de crime especial, em que está inserida a tutela dos princípios da hierarquia e disciplina, os quais não admitem aplicação do princípio da insignificância. Seguiram o voto do relator, sem nenhum acréscimo relevante, os Ministros Dias Toffoli, Ricardo Lewandowski, Marco Aurélio e as Ministras Carmem Lúcia e Ellen Gracie (BRASIL, 2010, p. 118-119, 125-132, 137-139).

Em sentido contrário, os Ministros Joaquim Barbosa, Celso de Mello e Cezar Peluso entenderam que, independentemente de se tratar do crime do art. 290 do CPM ou do art. 28 da Lei n. 11.343/2006, o que deve ser levado em consideração é a ínfima quantidade da substância entorpecente apreendida, que em razão disso não tem o condão de causar lesão ou risco de lesão ao qualquer bem jurídico tutelado, motivo pelo qual se deve aplicar o princípio da insignificância (BRASIL, 2010, p. 133, 140 e 143-144). O Ministro Gilmar Mendes seguiu o voto destes três últimos Ministros mencionados, mas destacou que defende a incidência do art. 28 e não do art. 290 do CPM, por ser aquele mais benéfico ao réu do que este (BRASIL, 2010, p. 135).

Ao final, por seis votos a quatro, prevaleceram as razões de decidir do relator, cuja fundamentação foi, em resumo do que já foi dito, de que se trata do crime próprio previsto no art. 290 do CPM e não do crime comum do art. 28 da Lei de Drogas; portanto, não se admite aferição de insignificância, devido a violação dos princípios da hierarquia e disciplina que regem de forma peculiar as relações castrenses, conforme disposição do art. 142 da CF.

Nota-se que a concretização da norma considerou os aspectos textuais, como a literalidade do CPM e da regulamentação constitucional acerca das Forças Armadas; os aspectos jurídicos, ao referirem-se a natureza da relação que envolvia o caso concreto; mas, deixou de analisar os fatores sociais e pragmáticos da decisão, ao ignorar o fato de que a ínfima quantidade de droga apreendida com o paciente seria incapaz de causar qualquer lesão ou risco de lesão a outrem senão a ele próprio, o que afasta a justificativa de imposição de sanção penal, podendo permanecer, quando muito, uma sanção de cunho disciplinar, em conformidade com o que apregoa a teoria do garantismo.

Fora dos casos envolvendo relações militares, a Primeira Turma do STF já adotou posicionamentos diferentes em dois casos similares. No primeiro, o julgamento do HC n. 102.940, em 2011, sob relatoria do Ministro Ricardo Lewandowski, único que se manifestou acerca do mérito, vez que o writ estava prejudicado pela ocorrência de prescrição, decidiu pela inaplicabilidade do princípio da insignificância ao art. 28 da Lei de Drogas, por meio da argumentação de que, por se tratar de crime de perigo abstrato, não seria necessária a caracterização da efetiva lesão à saúde pública (BRASIL, 2011, p. 117).

O Ministro Ricardo Lewandowski foi além, alegou que haveria real possibilidade de o usuário tornar-se traficante no futuro a fim de sustentar seu vício e, por isso, não estaria presente o requisito objetivo de ausência de periculosidade social da ação, motivo pelo qual se afasta a incidência da insignificância (BRASIL, 2011, p. 118). Nota-se que a justificativa do Ministro é completamente inadequada ao Estado Democrático e Constitucional de Direito, e fere, inclusive, os princípios da legalidade e da anterioridade da lei penal, pois o relator justifica a atribuição de punição à prevenção de uma possibilidade de futura ação criminosa diversa da qual o indivíduo está sendo julgado, o que é ilegítimo e ilegal, portanto, antigarantista.

No segundo caso, o julgamento do HC n. 110.475, em 2012, cujo relator foi o Ministro Dias Toffoli, a Primeira Turma, em decisão unânime, decidiu em sentido contrário ao acima relatado, pois entendeu ser aplicável o princípio da insignificância ao art. 28, tendo em vista a ínfima quantidade da substância apreendida, seis decigramas de maconha (BRASIL 2012, p. 1-2).

Destaca-se, no entanto, que a unanimidade da votação ocorreu, provavelmente, porque o Ministro Ricardo Lewandowski, cujo entendimento já foi exposto, não estava presente ao julgamento. Além do que, a Ministra Cármem Lúcia ressaltou que adotou um posiciomento excepcional em seu voto, pois defende a inaplicabilidade do princípio da insignificância ao art. 
28 da Lei de Drogas. Considerando o caso específico, ela entendeu que as consequências da punição seriam desproporcionais à quantidade de droga apreendida (BRASIL, 2012, p. 18-19).

No voto do relator Ministro Dias Toffoli, predominou o argumento de que o Direito Penal não deve se ocupar de condutas que não produzam lesão significativa a bens jurídicos relevantes e que as penas privativas de liberdade e restritivas de direitos somente se justificam quando estritamente necessárias a proteção das pessoas e da sociedade, voto que foi seguido pelas Ministras Rosa Weber e Carmem Lúcia (BRASIL, 2012, p. 9-10, 16 e 18). O Ministro Luiz Fux acrescentou ainda uma breve citação ao princípio da proporcionalidade para dizer que, no caso, não há o equilíbrio necessário entre o crime cometido e o castigo previsto (BRASIL, 2012, p. 17).

Deste modo, neste último julgado analisado, imperaram argumentos condizentes tanto com a teoria garantista, que, conforme amplamente mencionado, tem como escopo um Direito Penal mínimo, quanto uma análise em conformidade com a metódica estruturante, à medida que verificou as circunstâncias legais, a previsão normativa, a literalidade do artigo incriminador, mas não deixou de considerar as circunstâncias do caso concreto, a realidade, do fato e do autor. A Ministra Cármem Lúcia destacou que um dos motivos de seu voto foi a condição de vulnerabilidade do "viciado", que pioraria com a imposição de uma sanção penal.

Vale ressaltar que o RE n. 635.659, objeto de discussão sobre a constitucionalidade do art. 28 da Lei de Drogas, foi interposto em fevereiro de 2011, portanto, antes mesmo da decisão acima analisada ter sido prolatada (HC n. 110.475). No entanto, teve repercussão geral reconhecida apenas em março de 2012 e, até o presente momento, não foi objeto de decisão definitiva. O Ministro relator do caso prolatou o seu voto em agosto de 2015, e além dele, apenas outros dois Ministros se manifestaram, Edson Fachin e Luis Roberto Barroso.

Até o presente momento, não é possível identificar uma padronização hermenêutica nas razões de decidir do STF sobre a aplicação do art. 28 da Lei de Drogas, isto porque os Ministros tiveram poucas chances de analisar o mencionado dispositivo de forma mais profunda e, nas oportunidades em que o fizeram, primeiramente ao decidir a questão de ordem do RE n. 430.105, detiveram-se unicamente a critérios formais e, posteriormente, no caso que disse respeito às relações castrenses, pacificaram o entendimento pela inaplicabilidade dos princípios da insignificância e da ofensividade, não por causa do bem jurídico saúde pública, mas por ferir os princípios da hierarquia e disciplina militares.

Portanto, tendo em vista que ainda há divergência no posicionamento entre os Ministros do Tribunal acerca do art. 28 da Lei de Drogas nas relações comuns, vez que utilizaram de argumentos diferentes na fundamentação de decisões que tratavam de situações similares, especificamente nos casos dos HC n. 102.940 e HC n. 110.475, resta analisar os três votos já proferidos no RE n. 635.659 para tentar aferir se há uma possível previsibilidade do resultado final deste julgamento e se a solução prevista é a mais adequada ao Estado de Direito garantista.

\section{A POSSIBILIDADE DE DECLARAÇÃO DE INCONSTITUCIONALIDADE DO ART. 28 DA LEI DE DROGAS}

O RE n. 635.659, ora em julgamento no STF, refere-se ao caso em que Francisco Benedito Souza, pedreiro que cumpria pena por roubo, receptação e contrabando, foi flagrado dentro da cela portando, para em seguida consumir, três gramas de maconha, motivo pelo qual foi condenado pelo crime do art. 28 da Lei de Drogas à prestação de serviços comunitários pelo período de dois meses (SOUZA, 2015).

A Defensoria Pública do Estado de São Paulo, inconformada com a condenação do pedreiro, recorreu da sentença, que foi mantida pelo Tribunal de Justiça do Estado de São Paulo e pelo Superior Tribunal de Justiça até alcançar o STF, por meio do argumento de que o crime de porte de drogas para consumo próprio é inconstitucional, vez que fere os direitos fundamentais à 
privacidade e à intimidade, previstos no inciso $\mathrm{X}$ do art. $5^{\circ}$ da $\mathrm{CF}$, além de não ser viável para tutela da saúde pública, pois, quando muito, a conduta atinge apenas a saúde do próprio usuário (SOUZA, 2015).

O recurso foi interposto no STF em fevereiro de 2011 e distribuído para o relator Ministro Gilmar Mendes, em março do mesmo ano. Exatamente um ano depois, em março de 2012, teve repercussão geral reconhecida pelo Plenário Virtual daquela Corte. Desde então, aproximadamente, dezesseis interessados, dentre outros muitos que requereram e tiveram seus pedidos negados, habilitaram-se e manifestaram-se no processo como amici curiae.

Com muitos documentos, muitas páginas e discussões extrajurídicas permeando a questão, fruto de opiniões que vão desde os setores científicos das áreas de humanas e saúde, até o setor religioso da população, o Ministro relator prolatou seu voto somente em agosto de 2015, seguido, em setembro do mesmo ano, pelos votos dos Ministros Luiz Edson Fachin e Luís Roberto Barroso. Atualmente, o processo está suspenso devido a pedido de vista do Ministro Teori Zavascki. Tendo em consideração a ausência temporária de conclusão do caso, cabe analisar as razões de decidir dos três votos já manifestados.

O Ministro Relator Gilmar Mendes manifestou-se pela inconstitucionalidade do art. 28 da Lei n. 11.343/2006 e iniciou seu voto reconhecendo a liberdade do legislador para regulamentar os preceitos constitucionais em busca de garantir os direitos fundamentais neles previstos, porém, sempre sob a limitação imposta pelo princípio da proporcionalidade, que se refere à legitimidade dos meios utilizados e dos fins perseguidos, assim como a adequação dos meios à consecução dos fins pretendidos e a necessidade de utilização desses meios na falta de outros mais brandos (BRASIL, 2015a, p. 6).

A possibilidade de excesso cometido pelo legislador na sua atividade típica, ao desrespeitar as premissas da proporcionalidade acima dispostas, segundo o referido Ministro, abre margem para o controle constitucional material dos atos do Legislativo em matéria penal pelo STF, cuja função primordial, no atual panorama do Estado brasileiro, é de proteção à CF, na sua forma e conteúdo, com o fim último de assegurar os direitos fundamentais dos indivíduos e da sociedade (BRASIL, 2015a, p. 6).

Ao adentrar propriamente no mérito da questão, o Ministro Gilmar Mendes parte da premissa de que o simples fato de se tratar de crime de perigo abstrato não seria suficiente para entender pela inconstitucionalidade do dispositivo, pois reconhece que há casos em que a definição desse tipo de crime é a única forma que o legislador dispõe para tutelar bens jurídicos difusos e coletivos. Porém, para tais casos é necessário um amplo controle de constitucionalidade, sobretudo em razão da complicada relação de tais tipos penais com o princípio da ofensividade (BRASIL, 2015a, p. 12-13).

Destaca que a criminalização do porte para consumo próprio é contrária aos objetivos previstos na própria Lei de Drogas, especificamente nos artigos 18 a 23, que tratam da prevenção ao uso indevido, da atenção e da reinserção social dos usuários e dependentes, pois, ao criminalizar tal conduta, estigmatiza e marginaliza o usuário, que é taxado na sociedade como delinquente, situação, inclusive, agravada pela falta de critérios objetivos para diferenciar o usuário do traficante. Nas palavras do Ministro, fica evidente a inadequação da norma aos fins almejados, o que viola o princípio da proporcionalidade (BRASIL, 2015a, p. 17).

Ressalta, ainda, que não há estudos que comprovem que a criminalização do porte para consumo é eficaz no combate ao tráfico: pesquisas demonstram que países que já descriminalizaram a conduta de uso de entorpecentes não sofreram aumentos significativos no número de usuários ou dependentes, já que a proibição tem um impacto muito maior na decisão do consumo, do que a liberalidade. Não há, para o Ministro, justificativa plausível ou empírica para a tipificação da conduta, ora em análise, como crime (BRASIL, 2015a, p. 21-22).

No que diz respeito ao aspecto da necessidade de incriminação, o Ministro Gilmar Mendes defende que não vislumbra na ação tipificada qualquer ameaça à saúde pública, de modo 
que, se não há lesão, o tipo penal é desnecessário para o objetivo a que se propõe. Sem contar que a criminalização afeta o direito ao livre desenvolvimento da personalidade, extraído do princípio da dignidade da pessoa humana, pois a criminalização desrespeita a decisão da pessoa de colocar em risco sua própria saúde (BRASIL, 2015a, p. 38).

Para o Ministro, haveria outras medidas suficientes para restringir o consumo, o que afasta a imprescindibilidade da imposição de sanção penal. Seriam exemplos de meios mais brandos para o tratamento da questão a proibição do consumo em lugares públicos, a limitação das quantidades portáveis, a proibição administrativa de certas drogas, sob pena de sofrer sanções de natureza administrativa, dentre outras (BRASIL, 2015a, p. 39).

Os motivos mencionados foram determinantes para que o relator, Ministro Gilmar Mendes, declarasse a inconstitucionalidade do dispositivo, sem redução de texto, determinando o deslocamento da infração da esfera penal para a esfera administrativa, a quem caberá aplicar as medidas já previstas no dispositivo. O Ministro destaca a inconstitucionalidade do dispositivo como um todo, sem se referir especificamente a determinado tipo de droga. Reconhece a necessidade de estabelecimento de parâmetros objetivos para distinguir o traficante do usuário, mas deixa a cargo do Legislativo fazê-lo.

Observa-se, já nesse primeiro voto, a consonância com a Teoria Garantista de Ferrajoli: no primeiro momento, quando o Ministro destaca a limitação dos poderes do Estado com a finalidade de assegurar os preceitos constitucionalmente previstos, por meio da análise do princípio da proporcionalidade, que nada mais é do que a busca pelo equilíbrio entre a proibição do excesso e a proibição da insuficiência na função estatal de garantir direitos fundamentais e respeitar as liberdades individuais (SARLET, 2009, p. 268-269).

No segundo momento, quando faz referência expressa ao princípio da ofensividade, violado pelo art. 28 da Lei de Drogas, ressalta-se que este princípio corresponde a um dos principais pilares do garantismo, pois serve de justificação para a imposição de sanção penal, ou seja, a restrição à liberdade de alguém por meio da pena se justifica, apenas, se a lesão causada pela conduta do agente tiver sido minimamente lesiva. Portanto, o princípio da ofensividade é uma das formas mais importante de salvaguardar as liberdades individuais (FERRAJOLI, 2014, p. 429).

O segundo Ministro a se manifestar foi Luiz Edson Fachin, que partiu da premissa de que em casos envolvendo matéria de Direito Penal, tendo em vista os princípios da legalidade e da proporcionalidade, o STF deve se autoconter em suas manifestações, motivo pelo qual sua decisão abrange somente a substância entorpecente a que se refere o caso concreto que deu ensejo ao RE, de modo que para todas as demais drogas, deve continuar sendo aplicada a legislação vigente em todos seus aspectos (BRASIL, 2015b, p. 2).

O Ministro Luiz Edson Fachin faz sua análise partindo dos princípios da proporcionalidade e da ofensividade. No que diz respeito ao princípio da proporcionalidade, o Ministro destaca que a sanção penal não é a única forma de controle social, mas é a mais gravosa, daí surge à necessidade de se aferir a adequação de sua imposição, juízo que importa em saber se a incriminação é justificada. Neste diapasão, o Ministro reconhece que o dependente é vítima e não criminoso, devendo ser encarado como doente que precisa de tratamento que, por sua vez, deve ser fornecido pelo Estado, conforme art. 196 da CF (BRASIL, 2015b, p. 12-14).

Em relação ao princípio da ofensividade, o Ministro ressalta que apenas se justifica a restrição à autonomia e à liberdade do indivíduo por meio de sanção penal, se, no exercício desses direitos, houver dano efetivo a terceiro; do contrário, não somente o princípio da ofensividade é violado, mas também os preceitos próprios do Estado de Direito brasileiro, que fez a opção por um Direito Penal do fato e não do autor (BRASIL, 2015b, p. 7-8).

Com base em tais argumentos, o Ministro Luiz Edson Fachin encerrou seu voto declarando a inconstitucionalidade parcial do dispositivo, sem redução de texto, pois manteve penalmente proibido o porte de drogas para consumo próprio em relação a todas as demais 
drogas diversas da maconha. O Ministro, assim como Gilmar Mendes, reconheceu ainda a necessidade de o Poder Executivo estabelecer critérios objetivos para diferenciar o usuário do traficante e, para isso, prescreveu um prazo de noventa dias contados da decisão final, por meio de medida que deve permanecer em vigência até que o Legislativo atue.

Por fim, votou o Ministro Luís Roberto Barroso, que, assim como o Ministro Luiz Edson Fachin, optou por se manifestar apenas sobre o porte da maconha para consumo pessoal e fez questão de ressaltar que descriminalização não significa legalização, portanto, independentemente da decisão final, o porte para consumo continuará sendo ilícito, mas não mais para o Direito Penal, passando a ser infração administrativa, que pode abranger como sanção as mesmas já previstas na Lei de Drogas (BARROSO, 2015b, p. 1).

O Ministro Luís Roberto Barroso optou por dividir seu voto em duas classes de razões. Primeiramente falou das de cunho pragmático, em que fez uma comparação com as campanhas preventivas de consumo de cigarro comum, que demonstraram eficácia, enquanto $o$ proibicionismo para o consumo de substâncias entorpecentes aumentou o número de usuários, o que comprova que os resultados de campanhas de advertência, em médio prazo, são melhores que os da criminalização (BARROSO, 2015b, p. 5).

Alertou, ainda nas justificações práticas, que a criminalização gera um custo alto para o Estado, pois causa um aumento significativo da população carcerária, pois quanto mais presos, mais gastos para o governo, sem contar que o desvio da atenção para criminalização prejudica o fomento às ações públicas de saúde. A criminalização não protege a saúde pública, pelo contrário, compromete-a, pois dificulta o acesso do usuário ao tratamento (BARROSO, 2015b, p. $5-6)$.

Como fundamentos jurídicos, o Ministro apontou, primeiramente, o fato de os direitos fundamentais previstos no art. $5^{\circ}$, inciso $\mathrm{X}$, da $\mathrm{CF}$ pertencerem ao espaço da vida das pessoas que está imune a qualquer tipo de interferência externa. São espécies do gênero direito de liberdade, que se consubstancia em um valor essencial nas sociedades democráticas, que não pode ser tolhido por ninguém, salvo para proteger direitos de terceiros ou determinados valores sociais, o que não inclui, segundo o Ministro, a saúde pública, exceto em raro sentido, motivo pelo qual não é proibido o consumo de álcool e cigarro (BARROSO, 2015b, p. 7-8).

O Ministro destaca, ainda, que não há que se confundir Direito e Moral, vez que há comportamentos que a sociedade acha ruim, mas que deve tolerar, o que não quer dizer que o Estado não possa continuar combatendo o consumo de drogas, tendo em vista seus malefícios para saúde do indivíduo, mas não deve puni-lo por meio do Direito Penal, pois o contrário representa uma forma de autoritarismo e de paternalismo, que impede o indivíduo de fazer suas próprias escolhas existenciais, que, no caso do porte de drogas para consumo próprio, não ofende terceiro e, por isso, não pode ser criminalizado, tendo em vista o princípio da ofensividade (BARROSO, 2015b, p. 7-8).

Ainda nas razões jurídicas, o referido Ministro analisou a ofensa ao princípio da proporcionalidade a começar pelo critério da adequação, ao alegar que a criminalização do porte de drogas para consumo é inadequada para tutelar a saúde pública, pois mais prejudica as políticas voltadas à tutela desse bem jurídico do que beneficia, além de ter, até então, se mostrado ineficaz. Quanto à necessidade, o Ministro destaca que há controvérsias, pois outros países já adotaram medidas alternativas menos gravosas. Por fim, em relação à proporcionalidade em sentido estrito, os custos não estão compensando, vez que o consumo vem crescendo no sentido inverso dos investimentos na proibição (BARROSO, 2015b, p. 10).

Em resumo, o Ministro Luís Roberto Barroso votou, também, pela declaração parcial de inconstitucionalidade do dispositivo, por ausência de lesividade da conduta ao bem jurídico tutelado, bem como por inadequação, discutível necessidade e desproporcionalidade, o que faz com que a criminalização não seja razoável para lidar com os problemas das drogas. O Ministro 
foi além, pois, diferenciando-se dos Ministros Gilmar Mendes e Luiz Edson Fachin, propôs critérios quantitativos para distinguir usuários de traficantes até que se legisle a respeito.

Da acurada análise dos três votos até então prolatados no RE n. 635.659, em comparação com as decisões analisadas no tópico anterior, já se percebe uma flexibilização maior dos Ministros do Tribunal a critérios não mais puramente formais de análise do dispositivo, assim como, pelo menos até o presente momento, não houve nenhuma fuga ao texto legal. Portanto, os votos prolatados mostraram coerência com a metódica hermenêutica, que não se desvincula nem do Estado de Direito nem da realidade que influencia os casos concretos a que a norma se aplica, em consonância com o que defende Müller.

Verifica-se que, exceto pela última parte do voto do Ministro Luís Roberto Barroso, que extrapolou sua competência de julgador ao estabelecer parâmetros quantitativos para diferenciar os usuários dos traficantes, há de se observar uma tendência garantista nos votos prolatados, pois, em todos eles, os Ministros procuraram fundamentar seus posicionamentos na ausência de ofensividade da conduta de consumir drogas ao bem jurídico tutelado, o que condiz com a Teoria do Garantismo, para a qual a observância do princípio da lesividade é de natureza obrigatória na justificação de imposição da sanção penal (FERRAJOLI, 2014, p. 428).

Destaca-se, ainda em consonância com o garantismo, que os três votos consideraram a necessidade de resguardar o direito de autodeterminação dos indivíduos, próprio de um sistema em que se respeita, ao máximo, as liberdades individuais, sem perder de vista a imprescindibilidade de continuar combatendo o consumo de drogas, por meio de medidas administrativas menos gravosas àquele que optou por colocar sua saúde em risco e que, ao menos no que diz respeito ao Direito Penal, deve ter essa escolha respeitada e tolerada, ainda que seja dever do Estado zelar pela saúde pública, o que deve fazer de outras formas.

Vale destacar que, a proposta dos três Ministros é uma solução que respeita a literalidade e a vontade do legislador de continuar combatendo o porte para consumo próprio, bem como a realidade, pois leva em consideração que a sanção penal não tem sido eficaz nesse sentido; muito pelo contrário, tem causado mais prejuízos ao marginalizar e dificultar o acesso a programas de tratamento de saúde do que benefícios, motivo pelo qual merece ser repensada, solução esta condizente tanto com a metódica estruturante quanto com o garantismo.

Portanto, verifica-se que, caso os demais Ministros do STF optem por seguir um viés garantista e uma metódica estruturante, existe a probabilidade de o art. 28 da Lei n. 11.343/2006 vir a ser declarado inconstitucional, sem que se deixe de respeitar nem o texto da lei, nem a realidade subjacente ao caso. O que não se pode perder de vista é que todos os outros votos restantes precisam manter uma metódica hermenêutica de análise, ou seja, o Tribunal precisa decidir, em conjunto, se se propõe ou não a seguir uma teoria garantista, para poder gerar segurança jurídica e previsibilidade aos casos futuros.

\section{CONCLUSÃO}

No decorrer do presente artigo verificou-se tanto uma exposição teórica a respeito das principais teses que serviram de base à investigação que se propôs realizar, no caso, a teoria garantista de Luigi Ferrajoli e a metódica estruturante de Friedrich Müller, bem como dos documentos jurídicos relevantes para formação da pesquisa científica que aqui se consubstanciou, de modo que os objetivos específicos traçados foram alcançados em todos os seus aspectos em cada um dos tópicos desenvolvidos, motivo pelo qual é possível chegar-se à presente conclusão por meio de uma síntese a ser a seguir apresentada, para enfim responder qual seria o desfecho mais adequado para o julgamento do RE n. 635.659.

Inicialmente, sintetiza-se que no HC 103.684, julgado pelo Pleno do STF, prevaleceu a decisão pela inaplicabilidade do princípio da insignificância, não pelo fato de a conduta ofender a saúde pública, mas pelo fato de se tratar de crime específico cometido por militar em ambiente 
sob administração castrense, previsto no art. 290 do CPM, motivo pelo qual houve violação, segundo o Tribunal, de princípios peculiares às Forças Armadas, expressamente previstos no art. 142 da CF, sendo este o fator determinante que se pode extrair das razões de decidir do STF para o não afastamento da tipicidade material do delito e a consequente denegação da ordem no caso específico.

Não houve propriamente nesse julgamento, a análise da ofensa ao bem jurídico saúde pública frente à conduta de posse de droga para consumo pessoal, pois os Ministros se filiaram, na maior parte de suas fundamentações, aos valores próprios das Forças Armadas. Não há como se extrair desse posicionamento influência relevante para a decisão final do RE n. 635.659, cujo caso envolve o conflito da saúde pública com os direitos fundamentais à privacidade e à intimidade.

O julgamento do HC n. 102.940, que se refere ao art. 28 da Lei de Drogas em casos envolvendo indivíduo comum, sem relação específica com qualquer instituição estatal, também resultou da inaplicabilidade do princípio da insignificância ao crime de porte de drogas para consumo pessoal. No entanto, como visto, apenas o Ministro Ricardo Lewandowski manifestouse acerca do mérito, ao declarar que, no seu entendimento, por se tratar de crime de perigo abstrato, não haveria necessidade de efetivação ofensa ao bem jurídico tutelado. Os demais Ministros não proclamaram seus votos, tendo em vista a ocorrência de prescrição.

Deste modo, mais uma vez não se pode levar em consideração que essa decisão venha a influenciar o Pleno do Tribunal no RE n. 635.659, até porque o Ministro Ricardo Lewandowski sequer fundamentou sua decisão de forma mais aprofundada, e nem ao menos explicou porque entende que não é necessário observar o princípio da ofensividade nos crimes de perigo abstrato. Muito pelo contrário, apresentou uma razão antigarantista de justificação para aplicação da sanção penal, ao afirmar que o usuário possivelmente poderia tornar-se um traficante para sustentar o vício, antecipando, dessa forma a possibilidade de lesão e a consequente punição ao indivíduo.

Já no julgamento do HC n. 110.475, a Primeira Turma decidiu de forma unânime sobre a possibilidade de aplicação do princípio da insignificância ao crime do art. 28 da Lei 11.343/2006. Embora a Ministra Carmem Lúcia tenha ressalvado que a sua opinião, em regra, é pela inaplicabilidade do referido princípio, todos os Ministros reconheceram que a ínfima quantidade de drogas apreendida com o paciente tornaria impossível qualquer possibilidade de lesão, sequer de risco de lesão, a terceiro.

Esse caso pode ser utilizado como parâmetro para previsibilidade de uma possível decisão de inconstitucionalidade do art. 28 da Lei de Drogas no julgamento final do RE 635.659, não apenas porque todos os Ministros da Primeira Turma reconheceram aplicabilidade da insignificância no caso em questão, mas também porque houve uma fundamentação mais detida deles em relação aos princípios que regem o Direito Penal mínimo, numa perspectiva garantista, de modo que se pode extrair uma tendência, ao menos nesses Ministros, em aceitar que a criminalização da conduta de portar drogas para consumo próprio não é mais condizente com a realidade dos fatos.

No que diz respeito aos três votos já prolatados no RE n. 635.659, pelos Ministros Gilmar Mendes, Edson Fachin e Luís Roberto Barroso, verificou-se uma profunda análise acerca dos princípios da proporcionalidade e da ofensividade, próprios de um Estado de Direito que segue a teoria garantista, em que se busca, ao mesmo tempo, uma atuação estatal positiva a fim de garantir direitos fundamentais, porém, limitada pelas liberdades individuais, de modo que o exercício do jus puniendi se justifica apenas se destinar-se a evitar lesão a terceiros, o que não é o caso do crime do art. 28 da Lei n. 11.343/2006, que, quando muito, prejudica apenas o próprio consumidor.

Além do que, as fundamentações dos votos dos referidos Ministros também consideraram aspectos da realidade e da prática, ao mencionarem exemplos de pesquisas 
empíricas realizadas por institutos nacionais e internacionais que comprovam a ineficácia da política criminal proibicionista e a possibilidade de instituição de medidas alternativas mais brandas para lidar com o problema do consumo, seja porque outros Estados já as adotaram, seja porque campanhas de advertência ao uso de cigarros comuns, que não são proibidos, têm mostrado resultados positivos a médio prazo.

Ademais, a proposta feita pelos três Ministros para que a conduta continue sendo ilícito de natureza administrativa respeita a literalidade do dispositivo, a vontade do legislador de combater o consumo de drogas, e a sistemática da própria Lei n. 11.343/2006, que previu como objetivos, nos artigos 18 a 23, a prevenção ao uso indevido e promoção à atenção e à reinserção social do usuário e dos dependentes, que, para serem alcançados precisam de um passo além dos que já foram dados com a despanalização da conduta. Apesar disso, o usuário e o dependente continuam sendo estigmatizados como criminosos, o que os afasta das políticas públicas voltadas para sua condição de vulnerabilidade.

Portanto, por todas as razões expostas e pela consonância com a teoria garantista, de Luigi Ferrajoli, e com a metódica estruturante, de Friedrich Müller, embora não haja como se fazer uma previsão inteiramente correta da decisão final do Pleno do STF no julgamento do RE n. 635.659, o que confirma a hipótese apresentada na presente pesquisa, pode-se concluir que as razões de decidir dos votos até agora prolatados merecem ser seguidas pelos demais Ministros do Tribunal, pois amparam uma decisão mais adequada ao Estado de Direito.

Por fim, não se pode deixar de mencionar que há, especialmente nos dias de hoje, uma necessidade ainda maior de o STF uniformizar seu posicionamento acerca da questão das drogas levando em consideração argumentos comuns e coerentes, por meios de uma decisão íntegra e estável, capaz de refletir segurança jurídica para as relações sociais que, de algum modo, possam ser influenciadas por esse julgamento, como por exemplo, a dos dependentes com as instituições que oferecem tratamento público e gratuito para aqueles que desejam. É o que se espera do STF no Estado Democrático de Direito.

\section{REFERÊNCIAS BIBLIOGRÁFICAS}

ABBOUD, Georges. STF vs. vontade da maioria: as razões pelas quais a existência do STF somente se justifica se ele for contramajoritário. Revista dos Tribunais, São Paulo, ano 101, v. 921, p. 191-211, jul. 2012.

ATIENZA, Manuel. As razões do direito - Teoria da Argumentação Jurídica. São Paulo: Landy Editora, 2000.

BARROSO, Luís Roberto. Judicialismo e Ativismo Judicial. Realização: canal da UniCEUB no Youtube. Brasília: UniCEUB, 2015a. (80 min.), son., color. Disponível em: <https://www.youtube.com/watch?v=idAWyb9QGDs>. Acesso em: 20 out. 2015.

BARROSO, Luís Roberto. Descriminalização da maconha. Vida acadêmica, jurisdição constitucional e debates públicos. Luís Roberto Barroso blog, 12 set. 2015b. Disponível em: <http://www.luisrobertobarroso.com.br/?p=1203>. Acesso em: 27 out. 2015.

BATISTA, Nilo. Introdução crítica ao direito penal brasileiro. 12. ed. rev. at. Rio de Janeiro: Renavam, 2015.

BECCARIA, Cesare. Dos Delitos e Das Penas. Tradução de Paulo M. Oliveira. Rio de Janeiro: Nova Fronteira, 2011. 
BITENCOURT, Cezar Roberto. Tratado de direito penal - parte geral. 20. ed. São Paulo: Saraiva, 2014. v. 1.

BONAVIDES, Paulo. Apresentação. In: MULLER, Friedrich. Métodos de trabalho do Direito Constitucional. Tradução de Peter Naumann. 3. ed. Rio de Janeiro: Renovar, 2005.

BRASIL. Supremo Tribunal Federal. Habeas Corpus nº 84.412. Paciente: Bill Cleiton Cristovão ou Bil Cleiton Cristóvão ou Bil Cleiton Christoff ou Biu Cleyton Cristovão ou Bill Cleiton Cristoff ou Bil Cleyton Cristovão. Impetrante: Luiz Manoel Gomes Junior. Autoridade Coatora: Superior Tribunal de Justiça. Relator: Ministro Celso de Mello. Julgamento em: 19/10/2004, publicado no DJ - 00037 de 19/11/2004. Disponível em: <http://www.stf.jus.br/portal/jurisprudencia/listarJurisprudencia.asp?s1=(84412.NUME.+OU+84 412.ACMS.)\&base=baseAcordaos\&url=http://tinyurl.com/nofndrd $>$. Acesso em: 28 jul. 2015.

BRASIL. Supremo Tribunal Federal. Recurso Extraordinário nº 430.105 - QO. Recorrente: Ministério Público do Estado do Rio de Janeiro. Recorrido: Juízo de Direito do X Juizado Especial da Comarca do Rio de Janeiro e Juízo de Direito da $29^{\circ}$ Vara Criminal do Rio de Janeiro. Relator: Ministro Sepúlveda Pertence. Julgamento em: 13/02/2007, publicado no DJe 004 de 27/04/2007. Disponível em: <http://www.stf.jus.br/portal/jurisprudencia/listarJurisprudencia.asp?s1=(430105.NUME.+OU+4 30105.ACMS.)\&base=baseAcordaos\&url=http://tinyurl.com/nccn7gd.>. Acesso em: 25 out. 2015.

BRASIL. Supremo Tribunal Federal. Habeas Corpus no 103.684. Paciente: Evanildo Costa do Nascimento. Impetrante: Defensoria Pública da União. Autoridade Coatora: Superior Tribunal Militar. Relator: Ministro Ayres Britto. Julgamento em: 21/10/2010, publicado no DJe - 070 de 13/04/2011. Disponível em: <http://www.stf.jus.br/portal/jurisprudencia/listarJurisprudencia.asp?s1=\%28103684.NUME.+O U+103684.ACMS.\%29\&base=baseAcordaos\&url=http://tinyurl.com/qfls9ca>. Acesso em: 25 out. 2015.

BRASIL. Supremo Tribunal Federal. Habeas Corpus nº 102.940. Paciente: Admilson Pereira dos Santos. Impetrante: Defensoria Pública da União. Autoridade Coatora: Superior Tribunal de Justiça. Relator: Ministro Ricardo Lewandowski. Julgamento em: 15/02/2011, publicado no DJe - 065 de 06/04/2011. Disponível em: <http://www.stf.jus.br/portal/jurisprudencia/listarJurisprudencia.asp?s1=\%28102940.NUME.+O U+102940.ACMS.\%29\&base=baseAcordaos\&url=http://tinyurl.com/pmbmypf $>$. Acesso em: 25 out. 2015.

BRASIL. Supremo Tribunal Federal. Habeas Corpus $\mathrm{n}^{\circ}$ 110.475. Paciente: Pablo Luiz Malkiewiez. Impetrante: Daisy Cristine Neitzke Heuer. Autoridade Coatora: Superior Tribunal de Justiça. Relator: Ministro Dias Toffoli. Julgamento em: 14/02/2012, publicado no DJe - 054 de $15 / 03 / 2012$. Disponível em: <http://www.stf.jus.br/portal/jurisprudencia/listarJurisprudencia.asp?s1=\%28110475.NUME.+O U+110475.ACMS.\%29\&base=baseAcordaos\&url=http://tinyurl.com/o78ejb6>. Acesso em: 25 out. 2015.

BRASIL. Supremo Tribunal Federal. Recurso Extraordinário no 635.659 (em andamento). Voto do Ministro Gilmar Mendes. Recorrente: Francisco Benedito de Sousa. Recorrido: Ministério Público do Estado de São Paulo. Relator: Ministro Gilmar Mendes. Notícias de 20/08/2015a. 
Disponível em: <http://www.stf.jus.br/arquivo/cms/noticiaNoticiaStf/anexo/RE635659.pdf>. Acesso em: 10 set. 2015.

BRASIL. Supremo Tribunal Federal. Recurso Extraordinário no 635.659 (em andamento). Votovista do Ministro Edson Fachin. Recorrente: Francisco Benedito de Sousa. Recorrido: Ministério Público do Estado de São Paulo. Relator: Ministro Gilmar Mendes. Notícias de 10/09/2015b. Disponível em: <http://www.stf.jus.br/arquivo/cms/noticiaNoticiaStf/anexo/RE635659EF.pdf>. Acesso em: 29/10/2015.

CARVALHO, Salo de. A política criminal de drogas no Brasil: estudo criminológico e dogmático da Lei 11.343/06. 7. ed. rev. atual. e ampl. São Paulo: Saraiva, 2014.

FERRAJOLI, Luigi. Constitucionalismo principialista e constitucionalismo garantista. In: STRECK, Lênio Luiz; KARAN, André Trindade (Org.). Garantismo, hermenêutica e (neo) constitucionalismo: um debate com Luigi Ferrajoli. Porto Alegre: Livraria do Advogado, 2012, p. 8-68.

FERRAJOLI, Luigi. Direito e Razão: Teoria do garantismo penal. Tradução de Ana Paula Zomer Sica; Fauzi Hassan Choukr; Juarez Tavares; Luiz Flávio Gomes. 4. ed. São Paulo: Revista dos Tribunais, 2014.

FONTOURA, João Fábio Silva da. et al. Hermenêutica constitucional e pós-positivismo: notas sobre a metódica estruturante e sobre a técnica da ponderação. In: SIMPÓSIO NACIONAL DE DIREITOS CONSTITUCIONAL, 9., 2010, Joinville. Anais eletrônicos...Curitiba: ABDConst, 2011, p. 310-354. Disponível em: 〈http://www.abdconst.com.br/revista3/anaiscompletos.pdf〉. Acesso em: 26 nov. 2015.

GADAMER, Hans-Georg. Verdad y método II. Salamanca: Ediciones Sígueme, 2010.

GOMES, Luiz Flávio Gomes. Nova lei de tóxicos: descriminalização da posse de drogas para consumo pessoal. Migalhas, São Paulo, 23 ago. 2006. Disponível em: $<$ http://www.migalhas.com.br/dePeso/16,MI29019,11049-

Nova+lei+de+toxicos+descriminalizacao+da+posse+de+droga+para+consumo>. Acesso em: 30 nov. 2015.

IPPOLITO, Dário. O garantismo de Luigi Ferrajoli. Tradução de: Hermes Zaneti Júnior. Revista de Estudos Constitucionais, Hermenêutica e Teoria do Direito, São Leopoldo, v. 3, n. 1, p.34-41, jun. 2011. Semestral. Disponível em: <http://revistas.unisinos.br/index.php/RECHTD/article/view/733>. Acesso em: 25 set. 2015.

KELSEN, Hans. Teoria pura do direito. Tradução de João Baptista Machado. Coimbra: Arménio Amado, 1984.

LAKATOS, Eva Maria; MARCONI, Marina de Andrade. Fundamentos de metodologia científica. 5. ed. São Paulo: Atlas, 2003.

LUZ, Yuri Corrêa da. Princípio da insignificância em matéria penal: entre aceitação ampla e aplicação problemática. Revista direito GV, São Paulo, v. 8, n. 1, p.203-233, jun. 2012. Disponível em: <http://dx.doi.org/10.1590/S1808-24322012000100009>. Acesso em: 20 nov. 2015. 
MULLER, Friedrich. Métodos de trabalho do Direito Constitucional. Tradução de Peter Naumann. 3. ed. Rio de Janeiro: Renovar, 2005.

NEVES, Isadora Ferreira; TEIXEIRA, Anderson Vichinkeski. As influências do neoconstitucionalismo nos fenômenos do ativismo judicial e da judicialização da política no Brasil. Revista Seção Judiciária do Rio de Janeiro, Rio de Janeiro, v. 21, n. 39, p. 169-185, abr. 2014. Disponível em: <http://www4.jfrj.jus.br/seer/index.php/revista_sjrj/article/view/490>. Acesso em: 20 ago. 2015.

NUCCI, Guilherme de Souza. Leis penais e processuais penais comentadas. 6. ed. São Paulo: Revista dos Tribunais, 2012. v. 1.

PALMER, Richard. Hermenêutica. Lisboa: Edições 70, 1999.

SARLET, Ingo Wolfgang. Direitos fundamentais e proporcionalidade: notas a respeito dos limites e possibilidades da aplicação das categorias da proibição de excesso e de insuficiência em matéria criminal. In: NOVELINO, Marcelo (org.). Leituras complementares de Direito Constitucional: Teoria da Constituição. Salvador: Editora Juspodivm, 2009, p. 257-281.

SARMENTO, Daniel. O neoconstitucionalismo no Brasil: riscos e possibilidades. In: NOVELINO, Marcelo (org.). Leituras complementares de Direito Constitucional: Teoria da Constituição. Salvador: Editora Juspodivm, 2009, p. 31-67.

SCHEIFER, Camila Escorsin; MANDALOZZO, Silvana Souza Netto; CAMPAGNOLI, Adriana de Fátima Pillatti Ferreira. Judicialização da política no Brasil: o Poder Judiciário como guardião dos direitos fundamentais. Revista de Direito Brasileira, São Paulo, v. 14, n. 6, p. 158-172, ago. 2016. Disponível em: <http://www.rdb.org.br/ojs/index.php/rdb/article/view/396>. Acesso em: 17 maio 2017.

SOUZA, Francisco Benedito. 'Assumi para evitar confusão', diz réu no caso do STF que pode descriminalizar porte de drogas. $O$ Globo, São Paulo, 15 ago. 2015. Entrevista concedida a Mariana Sanches. Disponível em: <http://oglobo.globo.com/sociedade/assumi-para-evitarconfusao-diz-reu-no-caso-do-stf-que-pode-descriminalizar-porte-de-drogas-1-17192416>.

Acesso em: 25 out. 2015.

STRECK, Lênio Luiz. Verdade e consenso - Constituição, hermenêutica e teorias discursivas. 4. ed. São Paulo: Saraiva, 2012a.

STRECK, Lênio Luiz. Neoconstitucionalismo, positivismo e pós-positivismo. In: STRECK, Lênio Luiz; KARAN, André Trindade (Org.). Garantismo, hermenêutica e (neo) constitucionalismo: um debate com Luigi Ferrajoli. Porto Alegre: Livraria do Advogado, 2012b, p. 69-111.

TAVARES, André Ramos. Abertura epistêmica do Direito Constitucional. In: NOVELINO, Marcelo (org.). Leituras complementares de Direito Constitucional: Teoria da Constituição. Salvador: Editora Juspodivm, 2009, p. 13-29. 